\title{
The effect of dietary guar gum on the activities of some key enzymes of carbohydrate and lipid metabolism in mouse liver
}

\author{
BY JOHN C. STANLEY* AND ERIC A. NEWSHOLME \\ Department of Biochemistry, University of Oxford, South Parks Road, Oxford OX1 $3 Q U$
}

(Received 27 February 1984 - Accepted 19 October 1984)

\begin{abstract}
1. The effects of a $100 \mathrm{~g} / \mathrm{kg}$ substitution of guar gum on the body-weight gain, food consumption and faecal dry weight of mice fed on a high-sucrose diet and on the activities of hepatic glucose-6-phosphate dehydrogenase (EC 1.1.1.49), 6-phosphogluconate dehydrogenase (EC 1.1.1.44), malate dehydrogenase (oxaloacetatedecarboxylating) (NADP ${ }^{+}$) $(E C$ 1.1.1.40), ATP-citrate (pro-3S)-lyase ( $E C$ 4.1.3.8), 6-phosphofructokinase $(E C 2.7 .1 .11)$, pyruvate kinase $(E C 2.7 .1 .40)$ and fructose-1,6-bisphosphatase $(E C 3.1 .3 .11)$ were studied.

2. Guar gum had no effect on body-weight gain or food consumption but increased faecal dry weight.

3. Guar gum increased the activities of glucose-6-phosphate dehydrogenase, malate dehydrogenase (oxaloacetatedecarboxylating) (NADP ${ }^{+}$) and 6-phosphofructokinase expressed on a wet-liver-weight basis.

4. Guar gum increased the activities of glucose-6-phosphate dehydrogenase, malate dehydrogenase (oxaloacetatedecarboxylating)(NADP ${ }^{+}$), ATP-citrate (pro-3S)-lyase and 6-phosphofructokinase expressed on a liver-protein basis.

5. Guar gum increased the activities of glucose-6-phosphate dehydrogenase and malate dehydrogenase (oxaloacetate-decarboxylating) $\left(\mathrm{NADP}^{+}\right.$) expressed on a body-weight basis.

6. These results suggest that guar gum increases the flux through some pathways of hepatic lipogenesis when mice are fed on high-sucrose diets.
\end{abstract}

Dietary fibre as defined by Trowell et al. (1976) includes not only materials such as wheat bran and bagasse, which are removed during the refining of wheat and sugar cane respectively, but also the viscous polysaccharides such as guar gum, pectin and gum tragacanth. Guar gum is a storage galactomannan found in the endosperm of the seeds of the Indian cluser bean, Cyamopsis tetragonolobus. It has effects on lipid and carbohydrate metabolism in human subjects. Guar gum lowers serum cholesterol levels (Jenkins et al. 1975), improves glucose tolerance (Jenkins et al. 1978), reduces the secretion of gastric inhibitory polypeptide and gut glucagon-like immunoreactivity (Morgan et al. 1979), lowers insulin levels (Jenkins et al. 1978) and increases the faecal excretion of fat and bile salts (Jenkins et al. 1976). These studies of the effects of guar gum on the metabolism of human subjects have, of necessity, been largely confined to measurements of the concentrations of metabolites in the blood, urine and faeces. However, the ability of guar gum to alter the concentration of some hormones and metabolites in the blood raises the possibility that dietary guar gum, which never leaves the gut, could modify the metabolism of tissues such as the liver. For this reason the effect of guar gum on the metabolism of mouse liver was studied and the results are reported in the present paper.

The effects of qualitative and quantitative changes in the carbohydrate, fat and protein contents of the diet on the maximum catalytic activities of key liver enzymes have been extensively studied (for a review, see Romsos \& Leveillé, 1974). By contrast, the effects of guar gum on the activities of these enzymes have not been reported. Changes in the maximum catalytic activities of key enzymes of metabolism measured in vitro can be used as indicators of changes in flux through metabolic pathways in vivo (Newsholme et al. 1980). This approach has been used in the present work to investigate the effect of guar gum on the flux through some of the pathways of carbohydrate and lipid metabolism in the liver.

\footnotetext{
* Present address: Research Department, Nestlé Products Technical Assistance Co. Ltd, CH-1814 La Tour-de-Peilz, Switzerland.
} 
EXPERIMENTAL

\author{
Animals, diets and feeding techniques
}

Male adult BALB/c mice were obtained from OLAC $1976 \mathrm{Ltd}$, Bicester. Mice were housed individually in wire-mesh cages equipped with litter trays and were allowed access to Oxoid diet 41B (Oxoid Laboratory Products, London) and water ad lib. The animals were maintained in a light-controlled room (lights on $06.00-20.00$ hours) at a temperature of approximately $22^{\circ}$. At the beginning of the feeding period the mice were divided into two groups so that each group had a mean initial body-weight of $26.5 \mathrm{~g}$. All mice were $140 \mathrm{~d}$ old at this time. Mice were fed for $50 \mathrm{~d}$.

Oxoid Breeding Diet powder was prepared by grinding Oxoid Breeding Diet pellets (Oxoid Laboratory Products) and putting the material through a sieve of mesh size $1.5 \mathrm{~mm}$; it contained $(\mathrm{g} / \mathrm{kg})$ maize 100 , wheat 400 , maize germ 75 , soya bean 275 , fish meal 50 , molasses 25 , fat (tallow type) $12 \cdot 5$, distillers' dried solubles 25 , minerals and vitamins $37 \cdot 5$. The high-carbohydrate control diet consisted of Oxoid Breeding Diet powder thoroughly mixed with $500 \mathrm{~g}$ sucrose $/ \mathrm{kg}$. Calculation showed that the control diet contained $(\mathrm{g} / \mathrm{kg})$ carbohydrate 684 , fat 30 , protein 253 , dietary fibre 18 . Guar gum powder, which induced a high viscosity in solution, was obtained as clear gum (batch no. 0081, Hercules RG 30; Hercules Powder Co. Ltd, London). The experimental diet consisted of the control diet thoroughly mixed with 100 g guar gum $/ \mathrm{kg}$. Using the Atwater factors (Southgate \& Durnin, 1970), the values for metabolizable energy supplied by Oxoid Laboratory Products and allowing for the fact that guar gum contains $33 \mathrm{~g}$ protein $/ \mathrm{kg}$ (Cummings et al. 1978), it can be calculated that the energy content of the control diet was $15.9 \mathrm{~kJ} / \mathrm{g}$ and that of the guar gum diet was $14.5 \mathrm{~kJ} / \mathrm{g}$. Carbohydrate provided approximately $70 \%$ of the energy content of each diet.

On the first day of the $50 \mathrm{~d}$ feeding period, Oxoid diet $41 \mathrm{~B}$ was replaced by either the control or the guar-gum diet. Approximately $50 \mathrm{~g}$ powdered diet, distributed equally between a glass food dispenser and petri dish, were supplied daily to each mouse. The body-weight of each mouse was measured every morning throughout the feeding period immediately before the diet was given. During the last $7 \mathrm{~d}$ of the $50 \mathrm{~d}$ feeding period, the food consumption and faecal weight of each mouse was measured daily. Faeces were dried to constant weight in an oven at $60^{\circ}$ before weighing.

\title{
Preparation of liver extracts
}

Sources of all chemicals and enzymes have been given previously (Newsholme et al. 1979).

Mice were stunned by a blow on the head and killed by cervical dislocation. Livers were removed as rapidly as possible, weighed and divided into two portions. One portion was clamped between precooled $65-\mathrm{mm}$ diameter plates and plunged into liquid nitrogen. The frozen liver was wrapped in aluminium foil and stored in liquid $\mathrm{N}_{2}$. When required, these frozen liver samples were thawed as slowly as possible and used for the extraction and assay of 6-phosphofructokinase ( $E C$ 2.7.1.11), pyruvate kinase $(E C 2.7 .1 .40)$ and fructose1,6-bisphosphatase $(E C 3,1.3 .11)$. Preliminary experiments established that the activities of these enzymes were unaffected by freezing and thawing the liver (results not shown). Fresh liver was kept on ice and used for the extraction and assay of glucose-6-phosphate dehydrogenase (EC 1.1.1.49) 6-phosphogluconate dehydrogenase (EC 1 1 1.1.44), malate dehydrogenase (oxaloacetate-decarboxylating) $\left(\mathrm{NADP}^{+}\right)(E C$ 1.1.1.40) and ATP-citrate (pro-3S)-lyase ( $E C 4,1.3 .8$ ). Storage of liver samples in liquid $\mathrm{N}_{2}$ increased the number of enzymes that could be assayed in each mouse liver.

Weighed samples of fresh or frozen liver were chopped into small pieces with scissors and homogenized in 10 vol. extraction medium using a glass homogenizer and five passes 
of a loose-fitting Teflon pestle. Fresh liver was extracted in $250 \mathrm{~mm}$-sucrose, $20 \mathrm{~mm}$ Tris hydrochloride, $1 \mathrm{~mm}$-magnesium chloride, $10 \mathrm{~mm}$-dithiothreitol, $100 \mathrm{~mm}$-potassium

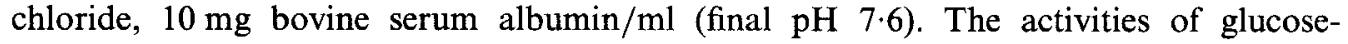
6-phosphate dehydrogenase, 6-phosphogluconate dehydrogenase, malate dehydrogenase (oxaloacetate-decarboxylating) $\left(\mathrm{NADP}^{+}\right.$) and ATP-citrate (pro-3S)-lyase were stable in this medium for up to $6 \mathrm{~h}$ on ice (results not shown). Frozen liver was either extracted in 250 mM-sucrose, $20 \mathrm{~mm}$-potassium phosphate, $100 \mathrm{~mm}$-ammonium sulphate, $10 \mathrm{mg}$ bovine serum albumin $/ \mathrm{ml}, 1 \mathrm{~mm}$-dithiothreitol, $0.2 \mathrm{~mm}$-phenylmethylsulphonyl fluoride, $2.4 \mathrm{~mm}$ fructose-6-phosphate (final $\mathrm{pH} 7 \cdot 4$ ) or $20 \mathrm{~mm}$-potassium phosphate, $100 \mathrm{~mm}$-potassium fluoride, 4 mM-EDTA, $250 \mathrm{~mm}$-sucrose, $1 \mathrm{~mm}$-dithiothreitol (final $\mathrm{pH} 7 \cdot 4$ ). The activity of 6-phosphofructokinase in the former medium and the activities of pyruvate kinase and fructose-1,6-bisphosphatase in the latter medium were stable for up to $6 \mathrm{~h}$ on ice (results not shown). Three separate extraction media were necessary because different enzymes require different conditions for stability. Samples of all liver extracts were centrifuged at $4^{\circ}$ for six 2-min periods at $12000 \mathrm{~g}$ in a precooled Eppendorf bench centrifuge (model no. 3200). The clear layer between the fat layer and the pellet was used for enzyme assays and protein determinations.

\section{Enzyme and protein assays}

Glucose-6-phosphate dehydrogenase, 6-phosphogluconate dehydrogenase and malate dehydrogenase (oxaloacetate-decarboxylating) $\left(\mathrm{NADP}^{+}\right.$) were assayed by measuring the rate of increase of absorbance at $340 \mathrm{~nm}$ due to the reduction of $\mathrm{NADP}^{+}$according to the methods of Newsholme et al. (1979). The assay medium for glucose 6-phosphate dehydrogenase and 6-phosphogluconate dehydrogenase contained : $50 \mathrm{~mm}$-Tris hydrochloride, $0 \cdot 2 \mathrm{~mm}-\mathrm{NADP}^{+}$, $20 \mathrm{~mm}$-magnesium chloride, either $2 \mathrm{mM}$-glucose-6-phosphate or 6-phosphogluconate (final pH 7.4). The assay medium for malate dehydrogenase (oxaloacetate-decarboxylating) $\left(\mathrm{NADP}^{+}\right)$contained $50 \mathrm{~mm}$-Tris hydrochloride, $0.2 \mathrm{~mm}-\mathrm{NADP}^{+}, 1 \mathrm{~mm}$-manganese chloride, 100 mm-potassium chloride, 1 mm-potassium malate (final pH 7.4). Rates of NADP ${ }^{+}$ reduction measured in the absence of glucose-6-phosphate, 6-phosphogluconate or potassium malate were used to correct for endogenous NADP ${ }^{+}$reduction.

ATP-citrate (pro-3S)-lyase was assayed by measuring the rate of decrease of absorbance at $340 \mathrm{~nm}$ by coupling the formation of oxaloacetate to the oxidation of NADH via the enzyme malate dehydrogenase (EC1 . 1 . 1 .37) according to the method of Inoue et al. (1966) modified as follows. The assay medium contained: $200 \mathrm{~mm}$-Tris hydrochloride, $10 \mathrm{~mm}-$ dithiothreitol, $10 \mathrm{~mm}$-magnesium chloride, $0.2 \mathrm{~mm}$-NADH, $5 \mathrm{~mm}$-ATP, 20 mm-potassium citrate, $10 \mathrm{~mm}$-creatine phosphate, $100 \mu \mathrm{g}$ creatine kinase $(E C 2.7 .3 .2), 2.5 \mu \mathrm{g}$ malate dehydrogenase, $5 \mu \mathrm{g}$ antimycin A, $0 \cdot 2 \mathrm{~mm}-\mathrm{CoA}$ (final $\mathrm{pH} 8 \cdot 4$ ). Rates of NADH oxidation measured in the absence of $\mathrm{CoA}$ were used to correct for endogenous NADH oxidation.

6-Phosphofructokinase was assayed by measuring the rate of decrease of absorbance at $340 \mathrm{~nm}$ by coupling the formation of fructose-1,6-bisphosphate to the oxidation of NADH via the enzymes fructose bisphosphate aldolase $(E C 4.1 .2 .13)$, triose phosphate isomerase $\left(E C\right.$ 5.3.1.1) and glycerol-3-phosphate dehydrogenase $\left(\mathrm{NAD}^{+}\right)(E C 1.1 .1 .8)$ according to the method of Brand \& Söling (1974) modified as follows. The assay medium contained: $50 \mathrm{~mm}$-triethanolamine hydrochloride, $5 \mathrm{~mm}$-dithiothreitol, $3 \mathrm{~mm}$-magnesium chloride, $200 \mathrm{~mm}$-potassium chloride, 0.34 mM-NADH, 2.4 mM-AMP, 2.4 mM-fructose-6-phosphate, $100 \mu \mathrm{g}$ fructose bisphosphate aldolase, $10 \mu \mathrm{g}$ triose phosphate isomerase, $10 \mu \mathrm{g}$ glycerol3-phosphate dehydrogenase $\left(\mathrm{NAD}^{+}\right.$), $5 \mu \mathrm{g}$ antimycin $\mathrm{A}, 0.6 \mathrm{~mm}$-ATP (final pH 8.0). Rates of NADH oxidation measured in the absence of ATP were used to correct for endogenous NADH oxidation.

Pyruvate kinase was assayed by measuring the rate of decrease of absorbance at $340 \mathrm{~nm}$ 
Table 1. The effect of guar gum on the food consumption and faecal dry weight of mice (Mean values for eight mice per diet)

\begin{tabular}{lcccc}
\hline \multicolumn{1}{c}{ Diet... } & Control & Guar gum & Difference & SED (14 df) \\
\hline Body-wt (g) & $29 \cdot 4$ & $30 \cdot 1$ & $0 \cdot 7$ & 0.48 \\
Food consumption (g/d) & $6 \cdot 2$ & $6 \cdot 1$ & $-0 \cdot 1$ & 0.23 \\
Food consumption (g/kg body-wt) & 212 & 203 & -9 & 6.5 \\
Faecal dry wt (g/d) & 1.3 & 1.4 & $0 \cdot 1$ & 0.07 \\
Faecal dry wt (g/kg food consumption) & 207 & 225 & $18^{*}$ & 6.7 \\
\hline
\end{tabular}

Values for the guar gum diet were significantly different from the corresponding values for the control diet (Students' $t$ test): ${ }^{*} P<0.05$.

Table 2. The effect of guar gum on the body-weight, final 24 food consumption, liver weight and liver protein concentration of mice

(Mean values for eight mice per diet)

\begin{tabular}{lcccc}
\hline \multicolumn{1}{c}{ Diet... } & Control & Guar gum & Difference & SED (14 df) \\
\hline Initial body-wt (g) & $26 \cdot 5$ & 26.5 & 0 & $0 \cdot 70$ \\
Final body-wt (g) & $29 \cdot 6$ & $30 \cdot 4$ & $0 \cdot 8$ & $0 \cdot 45$ \\
Food consumption (g/d) & $6 \cdot 4$ & $6 \cdot 5$ & $0 \cdot 1$ & $0 \cdot 22$ \\
Food consumption (g/kg body-wt) & 219 & 213 & -6 & $6 \cdot 5$ \\
Liver wt (g) & $1 \cdot 6$ & $1 \cdot 7$ & $0 \cdot 1$ & $0 \cdot 05$ \\
Liver wt (g/kg body-wt) & 56 & 55 & -1 & $1 \cdot 4$ \\
Liver protein concentration & 240 & 218 & -22 & $10 \cdot 3$ \\
(mg/g liver) & & & \\
\hline \hline
\end{tabular}

Values for the guar gum diet were not significantly different from the corresponding values for the control diet (Student's $t$ test).

by coupling the formation of pyruvate to the oxidation of NADH via the enzyme lactate dehydrogenase (EC 1.1.1.27) according to the method of Feliu et al. (1977) modified as follows. The assay medium contained: $50 \mathrm{~mm}$-glycylglycine, $11.25 \mathrm{mM}$-magnesium chloride, $100 \mathrm{~mm}$-potassium chloride, $0.15 \mathrm{mM}-\mathrm{NADH}, 1.25 \mathrm{~mm}$-ADP, $10 \mu \mathrm{g}$ lactate dehydrogenase, $5 \mu \mathrm{g}$ antimycin $\mathrm{A}$ and $5 \mathrm{~mm}$-phosphoenolpyruvate (final $\mathrm{pH} 7 \cdot 4$ ). Rates of NADH oxidation measured in the absence of phosphoenolpyruvate were used to correct for endogenous NADH oxidation.

Fructose-1,6-bisphosphatase was assayed by measuring the increase of absorbance at $340 \mathrm{~nm}$ by coupling the formation of fructose-6-phosphate to the reduction of NADP ${ }^{+}$via the enzymes glucosephosphate isomerase (EC 5.3.1.9) and glucose-6-phosphate dehydrogenase according to the method of Riou et al. (1977) modified as follows. The assay medium contained: $100 \mathrm{mM}$-Tris hydrochloride, $2.5 \mathrm{~mm}$-diethiothreitol, $2 \mathrm{mM}$-magnesium chloride, $2 \mathrm{~mm}$-ammonium sulphate, $0.05 \mathrm{~mm}$-EDTA, $0.2 \mathrm{~mm}^{-N A D P}{ }^{+}, 10 \mu$ g glucosephosphate isomerase, $10 \mu \mathrm{g}$ glucose-6-phosphate dehydrogenase, $10 \mathrm{~mm}$-creatine phosphate, $100 \mu \mathrm{g}$ creatine kinase, $10 \mu \mathrm{g}$ adenylate kinase (EC 2.7.4.3) and $70 \mu \mathrm{M}$-fructose-1,6bisphosphate, (final pH 7.5). Rates of $\mathrm{NADP}^{+}$reduction measured in the absence of fructose-1,6-bisphosphate were used to correct for endogenous $\mathrm{NADP}^{+}$reduction.

Changes in absorbance were measured at $25^{\circ}$ using a Gilford recording spectrophotometer (model no. 240). The final cuvette volume was $2 \mathrm{ml}$. Centrifuged liver extract was 
Table 3. The effect of guar gum on the activities of some mouse liver enzymes expressed on a wet weight basis (umol/min per $\mathrm{g}$ )

(Mean values for eight mice per diet)

\begin{tabular}{|c|c|c|c|c|}
\hline Diet... & Control & Guar gum & Difference & SED $(14 \mathrm{df})$ \\
\hline $\begin{array}{l}\text { Glucose-6-phosphate dehydrogenase } \\
\text { (EC 1.1.1.49) }\end{array}$ & 0.6 & $0 \cdot 9$ & $0 \cdot 3 * * *$ & 0.06 \\
\hline $\begin{array}{l}\text { 6-Phosphogluconate dehydrogenase } \\
(E C 1.1 .1 .44)\end{array}$ & $1 \cdot 7$ & $1 \cdot 8$ & $0 \cdot 1$ & $0 \cdot 15$ \\
\hline $\begin{array}{l}\text { Malate dehydrogenase (oxaloacetate- } \\
\left.\text { decarboxylating)(NADP }{ }^{+}\right)(E C 1.1 .1 .40)\end{array}$ & $14 \cdot 4$ & $18 \cdot 9$ & $4 \cdot 5 * * *$ & 0.94 \\
\hline $\begin{array}{l}\text { ATP citrate (pro } 3 S) \text {-lyase } \\
(E C 4.1 .3 .8)\end{array}$ & $2 \cdot 4$ & $2 \cdot 8$ & $0 \cdot 4$ & $0 \cdot 21$ \\
\hline Pyruvate kinase (EC 2.7.1.40) & $69 \cdot 1$ & $66 \cdot 4$ & $-2 \cdot 7$ & 4.79 \\
\hline 6-Phosphofructokinase (EC 2.7.1.11) & $2 \cdot 0$ & $2 \cdot 2$ & $0 \cdot 2^{*}$ & 0.08 \\
\hline $\begin{array}{l}\text { Fructose-1,6-bisphosphatase } \\
(\text { EC 3.1.3.11) }\end{array}$ & $15 \cdot 5$ & $15 \cdot 1$ & $-0 \cdot 4$ & 0.84 \\
\hline
\end{tabular}

Values for the guar gum diet were significantly different from the corresponding values for the control diet (Student's $t$ test): ${ }^{*} P<0.05 ;{ }^{* * *} P<0.001$.

preincubated at $25^{\circ}$ for $10 \mathrm{~min}$ in an assay medium omitting substrate. For enzyme assays the reaction was started by the addition of substrate and for controls the reaction was started with distilled water. Enzyme assays and controls were carried out in duplicate.

Protein was assayed using the Bio-Rad protein assay kit, which is based on the method of Bradford (1976), on samples of centrifuged liver extract prepared using the pyruvate kinase-fructose-1,6-bisphosphatase extraction medium which is free of bovine serum albumin. Assays were carried out in duplicate.

Enzyme activities are expressed as $\mu \mathrm{mol} / \mathrm{min}$ per $\mathrm{g}$ fresh weight liver, $\mathrm{nmol} / \mathrm{min}$ per $\mathrm{mg}$ protein and $\mu \mathrm{mol} / \mathrm{min}$ per $\mathrm{kg}$ body-weight.

\section{Statistical methods}

All results are expressed as mean values. The significance of the difference between two means was assessed using Student's $t$ test.

\section{RESULTS}

The effects of a $100 \mathrm{~g} / \mathrm{kg}$ substitution of guar gum on the food consumption and faecal dry weight of mice fed on a high carbohydrate diet are shown in Table 1. Mice given the guar-gum diet had a lower mean food consumption than mice given the control diet but this difference was not significant. When faecal dry weight was expressed relative to food consumption, guar gum significantly increased the mean faecal weight.

The effect of a $100 \mathrm{~g} / \mathrm{kg}$ substitution of guar gum on the body-weight gain of mice given a high-carbohydrate diet throughout the $50 \mathrm{~d}$ feeding period is shown in Table 2 . Body-weight gain was used to assess how closely matched the experimental and control groups of mice were. Although the mice given guar gum gained more weight, this difference was not significant.

The effects of a $100 \mathrm{~g} / \mathrm{kg}$ substitution of guar gum on final $24 \mathrm{~h}$ food consumption, liver weight and liver protein concentration of mice given a high-carbohydrate diet is shown in Table 2. The mean liver weights and protein concentrations of the experimental and control 
Table 4. The effect of guar gum on the activities of some mouse liver enzymes expressed on a protein basis ( $\mathrm{nmol} / \mathrm{min}$ per $\mathrm{g}$ )

(Mean values for eight mice per diet)

\begin{tabular}{|c|c|c|c|c|}
\hline Diet... & Control & Guar gum & Difference & $\operatorname{SED}(14 \mathrm{df})$ \\
\hline $\begin{array}{l}\text { Glucose-6-phosphate dehydrogenase } \\
(E C 1.1 .1 .49)\end{array}$ & $2 \cdot 6$ & $4 \cdot 0$ & $1 \cdot 4^{* *}$ & $0 \cdot 40$ \\
\hline $\begin{array}{l}\text { 6-Phosphogluconate dehydrogenase } \\
\text { (EC 1.1.1.44) }\end{array}$ & $7 \cdot 0$ & $8 \cdot 5$ & $1 \cdot 5$ & $0-77$ \\
\hline $\begin{array}{l}\text { Malate dehydrogenase (oxaloacetate- } \\
\left.\text { decarboxylating)(NADP }{ }^{+}\right)(E C 1.1 .1 .40)\end{array}$ & $60 \cdot 5$ & $87 \cdot 5$ & $27 \cdot 0^{* * *}$ & $5 \cdot 62$ \\
\hline ATP citrate $(p r o-3 S)$-lyase $(E C 4.1 .3 .8)$ & 9.9 & $12 \cdot 9$ & $3 \cdot 0^{*}$ & $1 \cdot 36$ \\
\hline Pyruvate kinase $(E C 2.7 .1 .40)$ & 289 & 306 & 17 & $20 \cdot 4$ \\
\hline 6-Phosphofructokinase $(E C 2.7 .1 .11)$ & 8.4 & $10 \cdot 2$ & $1 \cdot 8^{* *}$ & 0.55 \\
\hline $\begin{array}{l}\text { Fructose-1,6-bisphosphatase } \\
(E C 3.1 .3 .11)\end{array}$ & $64 \cdot 4$ & $69 \cdot 2$ & $4 \cdot 8$ & $2 \cdot 21$ \\
\hline
\end{tabular}

Values for the guar gum diet were significantly different from the corresponding values for the control diet (Student's $t$ test): ${ }^{*} P<0.05 ;{ }^{* *} P<0.01 ;{ }^{* * *} P<0.001$.

Table 5. The effect of guar gum on the activities of some mouse liver enzymes expressed on a body-weight basis ( $\mu \mathrm{mol} / \mathrm{min}$ per $\mathrm{kg}$ )

(Mean values for eight mice per diet)

\begin{tabular}{|c|c|c|c|c|}
\hline Diet... & Control & Guar gum & Difference & $\operatorname{SED}(14 \mathrm{df})$ \\
\hline $\begin{array}{l}\text { Glucose-6-phosphate dehydrogenase } \\
(E C 1.1 .1 .49)\end{array}$ & 35 & 47 & $12^{* *}$ & $4 \cdot 0$ \\
\hline $\begin{array}{l}\text { 6-Phosphogluconate dehydrogenase } \\
\text { (EC 1.1.1.44) }\end{array}$ & 93 & 101 & 8 & $8 \cdot 5$ \\
\hline $\begin{array}{l}\text { Malate dehydrogenase (oxaloacetate- } \\
\left.\text { decarboxylating)(NADP }{ }^{+}\right)(E C 1.1 .1 .40)\end{array}$ & 802 & 1033 & $231 * *$ & $59 \cdot 9$ \\
\hline ATP citrate $(p r o-3 S)$-lyase $(E C 4.1 .3 .8)$ & 131 & 151 & 20 & $14 \cdot 0$ \\
\hline Pyruvate kinase ( $E C 2.7 .1 .40)$ & 3844 & 3623 & -221 & $271 \cdot 4$ \\
\hline 6-Phosphofructokinase $(E C 2.7 .1 .11)$ & 111 & 120 & 9 & $5 \cdot 3$ \\
\hline $\begin{array}{l}\text { Fructose-1,6-bisphosphatase } \\
(E C \text { 3.1.3.11) }\end{array}$ & 858 & 821 & -37 & $39 \cdot 2$ \\
\hline
\end{tabular}

Values for the guar gum diet were significantly different from the corresponding values for the control diet (Student's $t$ test): ${ }^{* *} P<0 \cdot 01$.

groups of mice were not significantly different. The mean food consumption of the mice given guar gum was not significantly different from that of the controls. Preliminary experiments demonstrated a correlation between the activities of malate dehydrogenase (oxaloacetate decarboxylating)(NADP ${ }^{+}$) and 6-phosphogluconate dehydrogenase in individual mouse livers and the food consumption of individual mice given the control diet or the guar-gum diet in the $24 \mathrm{~h}$ immediately before death (results not shown). It was therefore important to prepare groups of control and experimental mice with a similar mean food consumption so that any changes in enzyme activity found could be attributed to guar gum alone. Table 2 shows that the increased enzyme activities seen in mice given guar gum (see 
below) cannot be attributed to a higher mean food consumption by this group in the $24 \mathrm{~h}$ before death.

A variety of units has been used to express enzyme activities in nutritional studies (Freedland, 1967). In the present work enzyme activities have been expressed on a liver fresh weight basis (Table 3), on a liver protein basis (Table 4) and on a body-weight basis (Table 5). These tables show that a $100 \mathrm{~g} / \mathrm{kg}$ substitution of guar gum significantly increased the activities of glucose-6-phosphate dehydrogenase and malate dehydrogenase (oxaloacetate decarboxylating)(NADP ${ }^{+}$), regardless of the units used, significantly increased the activity of 6-phosphofructokinase expressed on a wet weight and protein basis and significantly increased the activity of ATP-citrate (pro-3S)-lyase expressed on a protein basis.

\section{DISCUSSION}

Glucose-6-phosphate dehydrogenase and 6-phosphogluconate dehydrogenase catalyse key reactions of the pentose phosphate pathway, one function of which is to provide NADPH for fatty acid and steroid synthesis (Krebs \& Eggleston, 1974). The reaction catalysed by malate dehydrogenase (oxaloacetate decarboxylating) $\left(\mathrm{NADP}^{+}\right)$synthesizes the remaining NADPH required (Rognstad \& Katz, 1979) while the reaction catalysed by ATP-citrate (pro-3S)-lyase generates cytoplasmic acetyl-CoA for fatty acid and steroid synthesis (Lowenstein, 1971). Liver glycogen metabolized via the glycolytic pathway is an important precursor for fatty acid synthesis (Salmon et al. 1974). Key reactions of glycolysis in the liver are catalysed by 6-phosphofructokinase and pyruvate kinase while fructose-1,6bisphosphatase catalyses a key reaction of gluconeogenesis. The effects of qualitative and quantitative changes in the carbohydrate, fat and protein contents of the diet on the maximum catalytic activities of these enzymes have been studied previously (Romsos \& Leveillé, 1974) but studies of the effects of guar gum have not been reported.

The present work demonstrates that a $100 \mathrm{~g} / \mathrm{kg}$ substitution of guar gum increases the activities of several key enzymes of carbohydrate and lipid metabolism in the livers of mice fed on high-carbohydrate diets for $50 \mathrm{~d}$. Guar gum caused a striking increase in the activities of glucose-6-phosphate dehydrogenase and malate dehydrogenase (oxaloacetate decarboxylating)(NADP ${ }^{+}$). This finding suggests that the demand for NADPH derived from the pentose phosphate pathway and from the reaction catalysed by malate dehydrogenase (oxaloacetate decarboxylating) $\left(\mathrm{NADP}^{+}\right.$) increased in mice given guar gum. One reason for this increased demand for NADPH may be an increased rate of bile acid and cholesterol synthesis. Guar gum increases the rate of bile acid excretion in human subjects (Jenkins et al. 1976) and reduces the rate of cholesterol absorption by rat jejenum (Gee et al 1983) and this may lead to an increase in the rate of bile acid and cholesterol synthesis in the liver in an attempt to maintain the bile acid and cholesterol pool. Guar gum also increases the activities of ATP-citrate (pro-3S)-lyase and 6-phosphofruktokinase. An increased rate of bile acid and cholesterol synthesis would require a source of carbon which may be provided by an increased rate of glycolysis from glycogen and an increase in the rate of acetyl-CoA generation in the cytoplasm.

Since guar gum never leaves the gut, changes in hepatic metabolism could be mediated by changes in the rate of secretion of gastrointestinal hormones. Guar gum reduces the secretion of gastric inhibitory polypeptide and gut glucagon-like immunoreactivity in human subjects (Morgan et al. 1979). Since there are receptors for gut glucagon-like immunoreactivity on the surface of the hepatocyte membrane (Bataille et al. 1974), gastrointestinal hormones may have direct effects on hepatic lipogenesis. Alternatively, or in addition, guar gum could alter the rate at which lipogenic precursors are supplied to the liver due to changes in the rate of their absorption from the intestine. It has been shown 
that guar gum decreases the rate of absorption of carbohydrate in the perfused jejunum of the rat (Blackburn \& Johnson, 1981). Finally, the ability of guar gum to increase the rate of bile acid excretion (Jenkins et al. 1976) and reduce the rate of cholesterol absorption (Gee et al. 1983) could modify hepatic lipid metabolism and account for some of the findings in the present work.

The authors wish to acknowledge the generous financial support provided by the Wellcome Trust, and to thank Dr J. A. Jenkins for the gift of guar gum.

\section{REFERENCES}

Bataille, D., Freychet, P. \& Rosselin, G. (1974), Endocrinology 95, 713-721.

Blackburn, N. A. \& Johnson, I. T. (1981). British Journal of Nutrition 46, 239-246.

Bradford, M. M. (1976). Analytical Biochemistry 72, 248-254.

Brand, I. A. \& Söling, H. D. (1974). Journal of Biological Chemistry 249, 7824-7831.

Cummings, J. H., Southgate, D. A. T., Branch, W., Wiggins, H. S., Houston, H., Jenkins, D. J. A. \& James, W. P. T. (1978). Lancet i, 5-9.

Feliu, J. E., Hue, L. \& Hers, H.-G. (1977). European Journal of Biochemistry 81, 609-617.

Freedland, R. A. (1967). Journal of Nutrition 91, 489-495.

Gee, J. M., Blackburn, N. A. \& Johnson, I. T. (1983). British Journal of Nutrition 50, 215-224.

Inoue, H., Suzuki, F., Fukunishi, K., Adachi, K.\& Takeda, Y. (1966). Journal of Biochemistry (Tokyo) 60, $543-553$.

Jenkins, D. J. A., Leeds, A. R., Gassull, M. A., Houston, H., Goff, D. V. \& Hill, M. J. (1976). Clinical Science and Molecular Medicine 51, 8P-9P.

Jenkins, D. J. A., Newton, C., Leeds, A. R. \& Cummings, J. H. (1975). Lancet i, 1116-1117.

Jenkins, D. J. A., Wolever, T. M. S., Leeds, A. R., Gassull, M. A., Haisman, P., Dilawari, J., Goff, D. V., Metz, G. L. \& Alberti, K. G. M. M. (1978). British Medical Journal i, 1392-1394.

Krebs, H. A. \& Eggleston, L. V. (1974). Advances in Enzyme Regulation 12, 421-434.

Lowenstein, J. M. (1971). Journal of Biological Chemistry 246, 629-632.

Morgan, L. M., Goulder, T. J., Tsioladis, D., Marks, V. \& Alberti, K. G. M. M. (1979). Diabetologia $17,85-89$.

Newsholme, E. A., Brand, K., Lang, J., Stanley, J. C. \& Williams, T. (1979). Biochemical Journal 182, $621-624$.

Newsholme, E. A., Crabtree, B. \& Zammit, V. A. (1980). Ciba Foundation Symposium 73, 245-258.

Riou, J.-P., Claus, T, H., Flockhart, D., Corbin, J. \& Pilkis, S. J. (1977). Proceedings of the National Academy of Sciences, USA 74, 4615-4619.

Rognstad, R. \& Katz, J. (1979). Journal of Biological Chemistry 254, 11969-11972.

Romsos, D. R. \& Leveillé, G. A. (1974). Advances in Lipid Research 12, 97-146.

Salmon, D. M. W., Bowen, N. L. \& Hems, D. A. (1974). Biochemical Journal 142, 611-618.

Southgate, D. A. T. \& Durnin, J. V. G. A. (1970). British Journal of Nutrition 24, 517-535.

Trowell, H. C., Southgate, D. A. T., Wolever, T. M. S., Leeds, A. R., Gassull, M. A. \& Jenkins, D. J. A. (1976). Lancet i, 967. 